\title{
Wildfire Dynamics in Nepal from 2000-2016
}

\author{
Krishna Bahadur Bhujel $^{1 *}$, Rejina Maskey-Byanju ${ }^{1}$, Ambika P. Gautam $^{2}$ \\ ${ }^{1}$ Central Department of Environmental Science, Tribhuvan University, Kathmandu, Nepal \\ ${ }^{2}$ Kathmandu Forestry College, Tribhuvan University (Affiliated), Kathmandu, Nepal
}

\begin{abstract}
Increasing trends of wildfire in recent year has become a serious concern across the world. However, in the Nepalese context, there seem limited studies carried out in connection to wildfires. Thus, the present research was objectively carried out to find out the trends, compare the wildfire incidence, burnt area, burning days and density of wildfire in the period before 2016 (2000-2015) and 2016. For the purpose, the Moderate Resolution Imaging Spector-Radiometer (MODIS) satellite images of Nepal were archived and literatures related to wildfires were collected from various sources. The burnt areas were calculated and wildfire incidences were counted in the image using ArcGIS. The wildfire events of before and during 2016 were compared by using excel program. The result showed wildfire incidence and burnt area are in increasing trends over the 17 years. The wildfire incidences were higher (around $33 \%$ ) in 2016 in compared to the annual average incidences from 2000 to 2015. Similarly, there seems $42 \%$ more burnt areas in 2016 as compared to period from 2000 to 2015 . Moreover, there seem 38 average annual wildfire days during the period from 2000-2015; however 40 wildfire days were recorded in 2016 adding two more days. The pre-monsoon period was found highly prone to wildfire incidence than the other seasons. The wildfire density showed around 0.09 incidence and 3.4 hectares burnt area per square $\mathrm{km}$ in 2016 which was only 0.03 incidences with 1.4 ha burnt area per $\mathrm{km}^{2}$ during 2000-2015. The highest density of wildfire was recorded to be nearly 0.16 incidences with 6.4 ha burnt area per $\mathrm{km}^{2}$ in 2016 in Tarai region. The findings will be helpful tool to wildfire ecology, wildfire managers and policy makers.
\end{abstract}

Key words: Burnt area, wildfire densities, wildfires day, wildfire incidence

\section{Introduction}

Wildfire is a major environmental and ecological issue in the world. It was recognized as a global serious environmental process which has been influenced by the atmosphere and biosphere (Bowman et al., 2009). Globally, 350 MHa areas burned annually (Giglio et al., 2013). Around $0.4 \%$ of the global land surface is reportedly burned every year which covers 30 - 46 million $\mathrm{km}^{2}$ (Randerson et al., 2012). Over $80 \%$ of the global area burned is grassland and savannahs, primarily in Africa and Australia, but also in South Asia and South America, while the remaining 20\% wildfire incidence was recorded in forest and shrub-dominated regions (Flannigan et al., 2009). Wildfire magnitude is influenced by the distribution of forest resources (fuels), topography and favorable environmental conditions (climate, and day-to-day weather conditions) (Parisien \& Moritz, 2009). Fuels provide the raw material, while the climate variables regulate fire occurrence patterns (Zhao \& Running, 2010). The carelessness, unsustainable management of the forests and variation in climatic variables are the main causes of fire incidence in Asia (Streets et al., 2003).

${ }^{*}$ Corresponding author, email address: bhujelkb@gmail.com
Global temperatures have increased by $\sim 0.2^{\circ} \mathrm{C}$ per decade over the last thirty years (Hansen et al., 2010; Hartmann et al., 2013). Kothawale et al. (2010) have reported that the mean temperature during the pre-monsoon season (March-May) was the hottest in South Asian region. The annual air surface temperature trends are increasing in India (Rohini et al., 2016). The extreme severe heat waves $\left(>40^{\circ} \mathrm{C}\right)$ events were recorded on 11 April and 21 May in 2016 which is the rare events in nature before (Singh et al., 2017). In Nepal, changes in temperature and precipitation are the reliable evidences of increasing fire incidences (Negi et al., 2012). The decreasing pattern of precipitation and long spell of rain off days are the evidences of severe wildfire in coming days (Wang et al., 2013).

Nepal has been experiencing irregular wildfire events in recent years during the dry season from November to June every year. The evidence showed that number of wildfire is increasing in Nepal, and affecting natural vegetation (Parajuli et al., 2015). The wildfire incidence was remarkably higher in 2016 (Jenner, 2017). 
The study of actual scenario of wildfire activities during 2000-2015 and in 2016 in Nepalese context is still scanty. In this context, several questions are raised regarding the noticeable wildfire events in 2016, some important questions are: whether there is large number of wildfire incidences in 2016 compared to 20002015 , what is the pattern of wildfire incidences in the period between 2000 and 2016? Thus, the present research has tried to answer these questions, as the research was objectively carried out to compare the wildfire incidence, burnt area, burning days and density of wildfire from 2000 to 2015 and during 2016.

\section{Materials and Methods Study area}

The study area covers whole geographical area of Nepal, which is situated between latitude $26^{\circ} 22^{\prime} \mathrm{N}$ and $30^{\circ} 27^{\prime} \mathrm{N}$, and longitude $80^{\circ} 40^{\prime} \mathrm{E}$ and $88^{\circ} 12^{\prime} \mathrm{E}$ with area coverage $147181 \mathrm{~km}^{2}$. Nepal is divided into five physiographic zones like High Himalayan, High Mountain, Middle Mountain, Siwalik and Tarai (Fig.1). The High Himalaya region includes the highest Himalayan massifs. The High Mountain region is characterized by the rugged landscape and very steep slopes. The Middle Mountains region lies north of Siwalik along the southern flanks of the High Mountain.

Siwalik region is the youngest mountain range, across the southern part of Nepal which is embedded with the just north of Tarai. The Tarai consists of flattened and gentle slope having high fertile land. Nepal mostly exhibits mountainous terrain with elevation ranging from $58 \mathrm{~m}$ to $8848 \mathrm{~m}$ amsl at Mount Everest. Nepal is home to 35 forest types, 75 vegetation types and 118 ecosystems, along the four global biodiversity hotspots (Chettri et al., 2008). However, these ecosystems have been facing severe challenges of natural and anthropogenic induced climate change events. Total forest and other wooded land together comprise 44.74\% (6.61 million ha) of the total area of the country (DFRS Nepal, 2015). The distribution of forest ecosystems can be observed distinctly according to altitudinal gradient from less than $1000 \mathrm{~m}$ to $4000 \mathrm{~m}$. The broad forest types in Nepal are tropical (below $1000 \mathrm{~m}$ ), subtropical broadleaved forests (1000-2000 m), subtropical pine forests (1000-2200 m), lower temperate mixed broadleaved forests (1700-2200 m), lower temperate broadleaved forests (1700-2700 $\mathrm{m})$, temperate coniferous forests (2000-3000 m), upper temperate broadleaved forests (2200-3000 m), upper temperate mixed broadleaved forests (2500-3500 m), subalpine forests (3000-4100 m), alpine shrub (above $4100 \mathrm{~m}$ ) (FRA 2000).

There are four climatological seasons namely pre-monsoon (March-May) that is hot and dry, the summer monsoon (June-September) is characterized by high humidity and precipitation, the post-monsoon (October-November) with reduced rainfall and winter (December-February) that is dry and cold (Kansakar et al., 2004). The temperatures in the Tarai and Mid-Hill region of Nepal are gradually increasing over the last few decades and expected to rise by $1.48^{\circ} \mathrm{C}, 2.88^{\circ} \mathrm{C}$ and $4.78^{\circ} \mathrm{C}$ respectively by 2030, 2060 and 2090 (Pradhan et al., 2013). The amount of precipitation and its distribution is determined by the annual monsoon system. The changes scenario of temperature and precipitation regimes helps to increase the number of wildfires in Nepal.

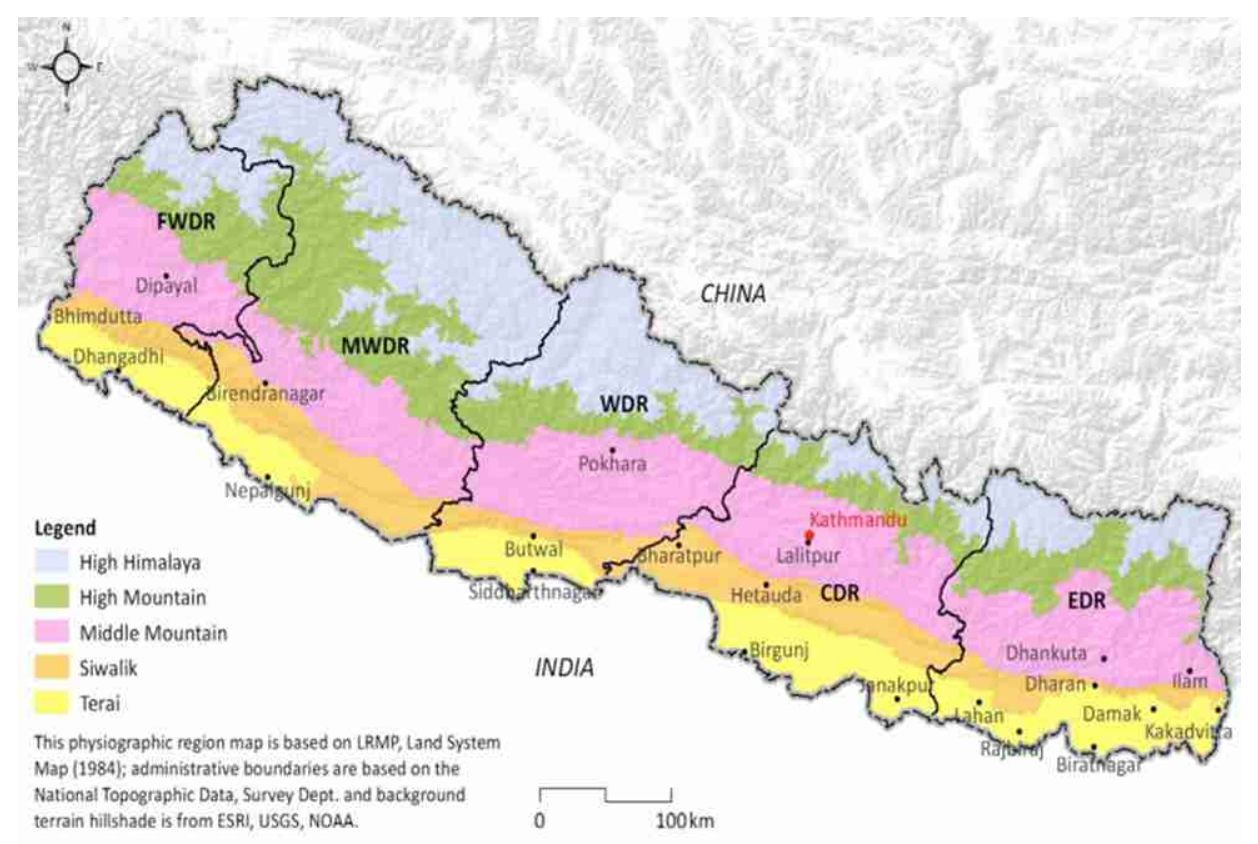

Figure 1 : Physiographic regions of Nepal (Adapted from DFRS, 2015) 


\section{Data sources and collection methods}

The active fire data was acquired from the Moderate-Resolution Imaging Spectroradiometer (MODIS) device on NASA's Terra and Aqua satellites during the period 2000-2016 as data source for mapping and analyzing the wildfire incidences and forest burnt area. The resolution of MODIS image is $1 \mathrm{~km} \times 1 \mathrm{~km}$ which records four times fire incidence observations per day basically on 1030 and 2200 hours from Terra and 0130 and 1330 hours from Aqua. During this period, wildfire incidences were driven from MODIS with confidence levels of $1-100 \%$, but we use the high confidence data set (showing over $50 \%$ confidence level). The total numbers of wildfire incidence was divided into two categories like period from 2000 to 2015 and in 2016. The coordinates of wildfire points and the date of wildfire incidences were obtained from the MODIS active fire products (version 5.1:https://firms.modaps.eosdis. nasa. gov/download/).

The data related to burnt area were acquired from MODIS in the form of GEOTIFF images having the clear distinguishable pixels of burnt area (including burnt-date information). The monthly burnt area product (MCD45A1) having level 3 gridded $(500 \mathrm{~m}$ resolution) was downloaded from the ftp server (ftp://ba1.geog. umd.edu/Collection5/TIFF/Win18/). In the next step, pixels showing the burnt area were extracted. The extracted image was processed geospatially in Arc Map 10.1. Then, the data showing the wildfire incidence and burnt area were categorized into two groups particularly data from 2000 to 2015 under first group and data of 2016 under second group. The accuracy of burnt area and number of wildfire incidence was checked/verified by comparing with the general accuracy statement of MOD14 product performance and direct field observation. Moreover, the desktop review of related literatures was carried out to explore the incidence and burnt area. The literature includes newspaper, article, report and electronic media.

\section{Data analysis}

The collected data of wildfire incidence and burnt area were analyzed using Microsoft Excel. The trends analysis and desktop review were used to find the trends of wildfire events and to compare the wildfire incidence, burnt area, burning days and density of wildfire from 2000 to 2015 and in 2016. The affected polygons showing the wildfire were counted and their areas were calculated. The clip function was applied to extract the wildfire affected area in ArcGIS. Moreover, the comparision maps of wildfire incidence were prepared by using the similar process of ArcGIS. In addition, the wildfire incidence and burnt area are presented in the climatological seasons namely pre-monsoon period (MarchMay), summer monsoon (June-August), post-monsoon (SeptemberNovember) and winter (December-February).

\section{Results and Discussion \\ Wildfire trends}

Spatially and temporally, wildfire incidents and burnt areas were found to be varying. Over all recorded wildfire incidences were 35374 and the burnt area was 1723920 ha from 2000 to 2016 in Nepal. The higher wildfire incidences and burnt area detected in the years 2005, 2009, 2012, 2014 and 2016. Moreover, the wildfire incidences and burnt area were found to be increased over the 17 years period (Fig. 2), which may be due to the accumulation of huge fine fuel like dry and thick ground litter, grasses and coarse fuel particularly debris, stumps, dry branches, litters, bush and log are highly influencing materials to accelerate the wildfire. Huang et al. (2015) showed that about $27 \%$ wildfire incidence probably increase by 2050 relative to the 2000 levels in the world. Pechony and Shindell (2010) depicted that an unprecedentedly fire-prone environment in future may be the cause of climate change. Moreover, Girardin and Mudelsee (2008) showed that there may be increase in wildfire by about $34 \%$ by 2061 and 2100 in northwestern Ontario and eastern boreal Manitoba. Similar results

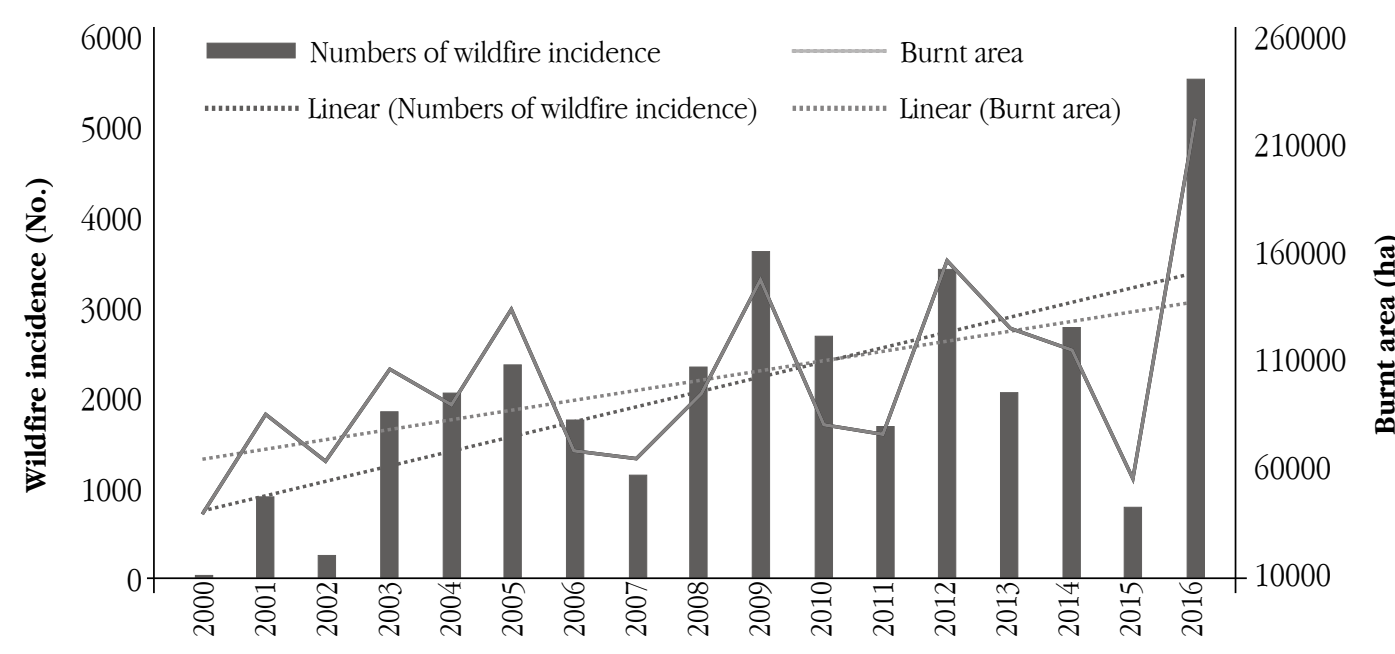

Figure 2 Month wise wildfire incidence and burnt area (Source: MODIS images from 2000 to 2016) 
have been shown by Westerling et al. (2006), which depicted that the catastrophic wildfires have been increased in recent decades in both Southern United States and other parts of the world. These findings support the results of the present research work.

\section{Month wise wildfire activities}

The months of wildfire incidence were found to be increased in 2016 compared to the average annual wildfire incidence before 2016 (2000-2015). The higher wildfire incidence 5394 (72\%) occurred in April 2016, whereas in the same month there was average 940 (52\%) wildfire incidence from 2000 to 2015. It was followed by March, May and February (Fig. 3). This indicates that the April is the most wildfire vulnerable month in compared to other months.

\section{Wildfire activities}

The analysis showed that there was the variation in overall annual wildfire incidences and burnt areas. The higher incidences 5630 and burnt area 222046 ha was recorded in 2016 in compared to average annual incidence 1865 and burnt area 93867 ha from 20002015 (Fig. 4). Moreover, the status of wildfire incidence during 2000-2015 and 2016 was demonstrated in the maps, which compare status of wildfire incidence (Fig. 5).

The similar results showed in India, with 30\% increase in wildfire incidence in April 21, 2016 compared to 2015 during fourth months of active fire reason (Mallapur, 2016). This result is in consistent to the present findings.

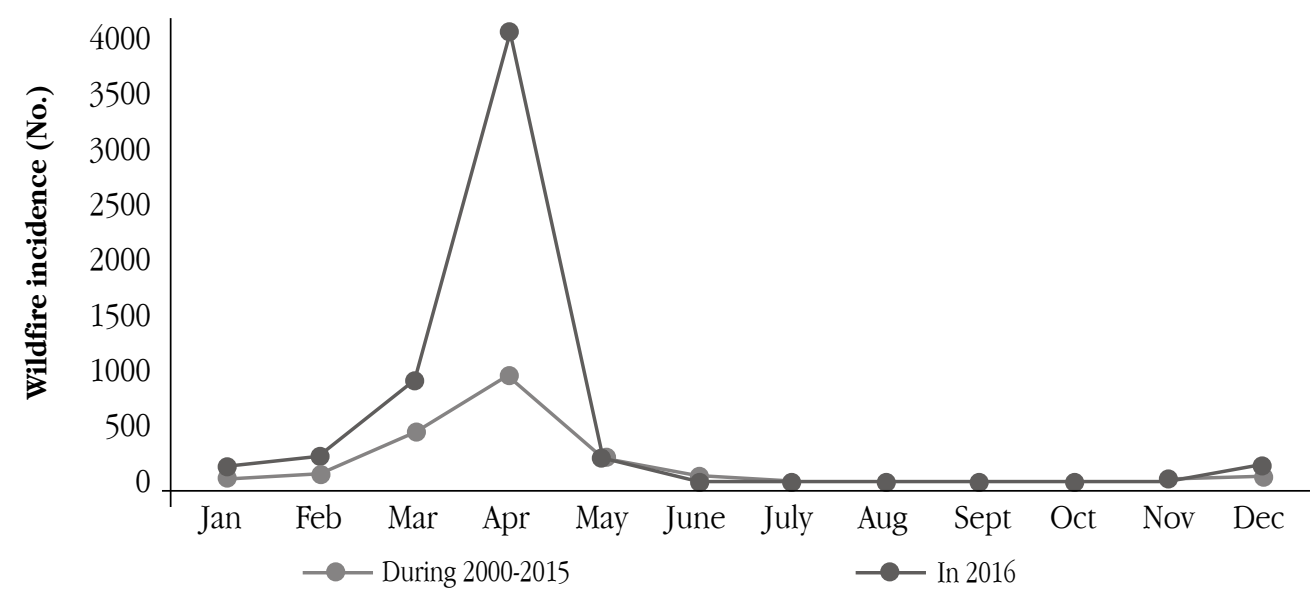

Figure 3 Month wise average annual wildfire incidence

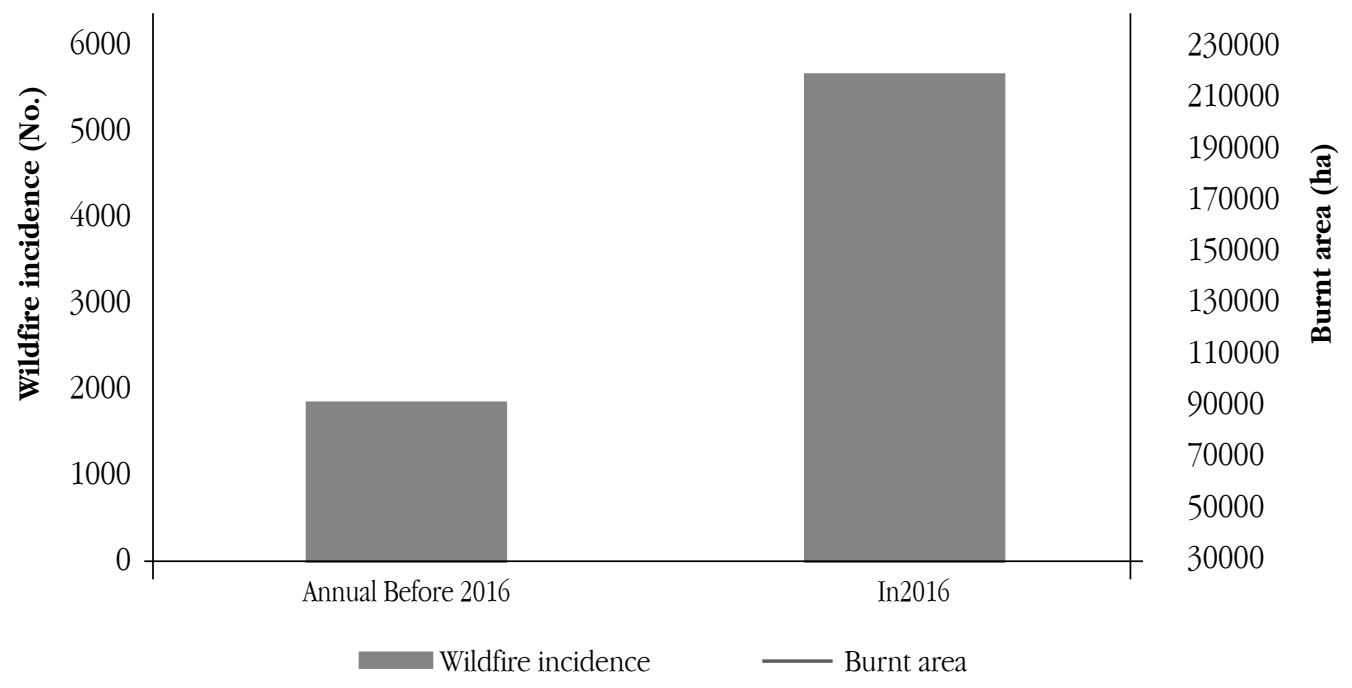

Figure 4 Wildfire activities during 2000-2015 and in 2016

\section{璃 TU-CDES}




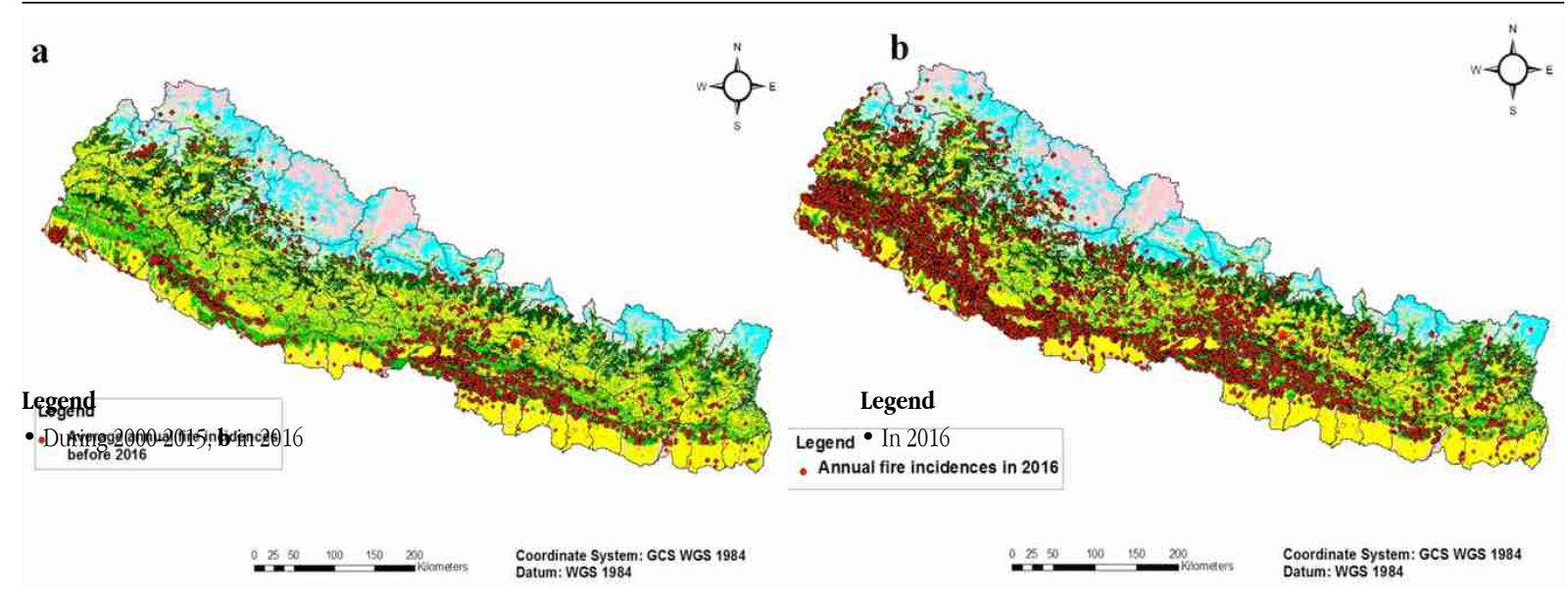

Figure 5 Wildfire incidence a during 2000-2015, b in 2016

\section{Seasonal wildfire activities}

The higher wildfire incidence record was found in pre-monsoon and winter seasons in 2016 compared to period from 2000 to 2015 (Fig. 5). Approximately $90 \%$ wildfire incidences were recorded in pre-monsoon season (March, April and May), while $87 \%$ were recorded during 2000-2015 in the same season. Similarly, winter was recorded as the second highest wildfire incidence season during 2000-2015 as well as in 2016. However, no wildfire incidence recorded during summer and post-monsoon seasons. Matin et al. (2017) showed the $89 \%$ wildfires occurrence during the premonsoon season (March-May) in Nepal. Similar study carried out by Shu et al. (2001) depicted that the most fire-hit time is February, March and April in South and Southwest forest areas in China. Moreover, observed higher wildfires were reported in central India during the March and April due to long dry seasons and droughts (Giriraj et al., 2010). These are supportive to the present research findings.

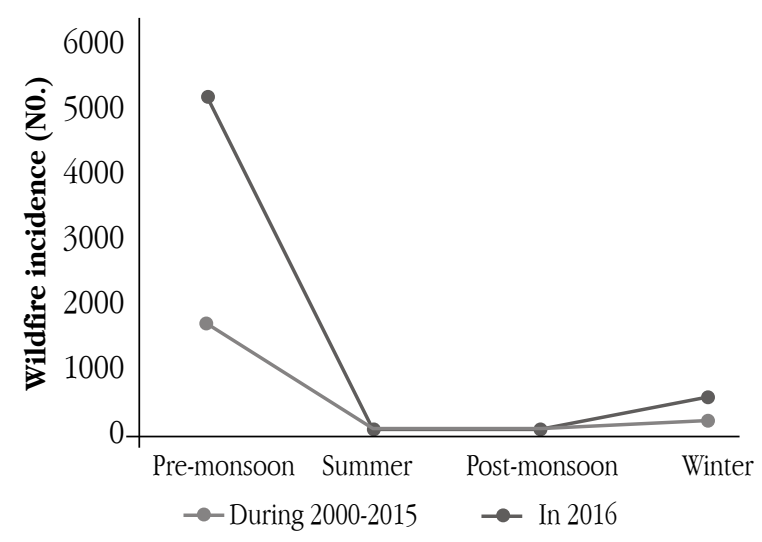

Figure 6 Seasonal average wildfire incidences

\section{Length of wildfire days}

The annual record of wildfire days found more in 2016 in comparison to period from 2000 to 2015. Specifically, there were more wildfire days (140) in 2016. However, it was less (138) days during 2000-2015. On an average, 40 wildfire incidences with 1586 ha forest burnt area per day recorded in 2016 and only 14 incidences with 640 ha forest burnt area per day was found during 2000-2015 showing 35\% wildfire incidence with 40\% burnt area higher in 2016 compared to period from 2000 to 2015.

Moreover, the higher numbers of wildfire days (25) recorded in April. Around 166 incidences with 7528 ha burnt area per day were recorded in 2016. There were about 38 incidences with 1894 ha burnt area per day in the same month during 2000-2015 (Table 1). Similarly, the March, May and December were recorded as the second, third and fourth month of higher wildfire days, respectively. The July and August were recorded with nageglible wildfire days and months like January, February, September, October and November were recorded as months with no wildfire days. Bowman et al. (2017) showed an increase in days conducive to extreme wildfire events by $20 \%$ to $50 \%$ in the disaster-prone landscapes, particularly in sub-tropical Southern Hemisphere and European Mediterranean Basin. This finding is also consistent with the present study. Moreover, Yue et al. (2013) depicted that wildfire is nearly 65\% in the Pacific Northwest, Eastern Rocky Mountains/ Great Plains regions. Richtel and Santos (2016) showed wildfire season has increased significantly longer in the past 30 years in New Mexico. All these results are in agreement with the present research findings. 
Table 1: Length of average annual wildfire days

\begin{tabular}{|c|c|c|c|c|c|c|c|c|c|c|}
\hline \multicolumn{6}{|c|}{ Average annual wildfire days during 2000-2015 } & \multicolumn{5}{|c|}{ Annual wildfire days in 2016} \\
\hline Month & $\begin{array}{c}\text { Wildfire } \\
\text { Days }\end{array}$ & $\begin{array}{c}\text { Wildfire } \\
\text { incidence }\end{array}$ & $\begin{array}{c}\text { Burnt } \\
\text { area ha }\end{array}$ & $\begin{array}{c}\text { incidence } \\
\text { /day }\end{array}$ & $\begin{array}{c}\text { burnt } \\
\text { area ha/day }\end{array}$ & $\begin{array}{l}\text { Wildfire } \\
\text { Days }\end{array}$ & $\begin{array}{c}\text { Wildfire } \\
\text { Days }\end{array}$ & $\begin{array}{l}\text { Burnt } \\
\text { area ha }\end{array}$ & $\begin{array}{c}\text { incidence } \\
\text { /day }\end{array}$ & $\begin{array}{c}\text { burnt } \\
\text { area ha/day }\end{array}$ \\
\hline Jan & 9 & 22 & 1107 & 3 & 123 & 24 & 142 & 5666 & 6 & 236 \\
\hline Feb & 16 & 80 & 4026 & 5 & 252 & 24 & 221 & 10051 & 9 & 402 \\
\hline Mar & 24 & 442 & 22246 & 18 & 927 & 19 & 885 & 18798 & 47 & 989 \\
\hline Apr & 25 & 940 & 47362 & 38 & 1894 & 25 & 3991 & 180672 & 166 & 7528 \\
\hline May & 19 & 239 & 12029 & 13 & 633 & 14 & 199 & 5329 & 14 & 381 \\
\hline June & 7 & 42 & 2114 & 6 & 302 & 2 & 6 & 0 & 3 & 0 \\
\hline July & 0 & 0 & 0 & 1 & 0 & 0 & 0 & 0 & 0 & 0 \\
\hline Aug & 0 & 0 & 0 & 1 & 0 & 0 & 2 & 0 & 0 & 0 \\
\hline Sept & 2 & 3 & 151 & 2 & 75 & 2 & 2 & 22 & 1 & 11 \\
\hline Oct & 4 & 6 & 302 & 2 & 75 & 5 & 12 & 0 & 2 & 0 \\
\hline Nov & 14 & 34 & 1711 & 2 & 122 & 14 & 24 & 202 & 2 & 14 \\
\hline Dec & 18 & 54 & 2818 & 3 & 157 & 11 & 146 & 1304 & 4 & 9 \\
\hline Total & 138 & 1865 & 93867 & 93 & 4561 & 140 & 5630 & 222046 & 254 & 9571 \\
\hline \multicolumn{2}{|c|}{ Average wildfire - } & - & - & 14 & 680 & - & - & - & 40 & 1586 \\
\hline
\end{tabular}

Table 2 : Wildfire densities

\begin{tabular}{|c|c|c|c|c|c|c|c|c|c|}
\hline \multicolumn{6}{|c|}{ Wildfire densities during 2000-2015 } & \multicolumn{4}{|c|}{ Wildfire densities in 2016} \\
\hline $\begin{array}{c}\text { Physiographica } \\
\text { region A } \\
\end{array}$ & $\begin{array}{c}\text { Forest } \\
\text { Area in } \mathrm{km}^{2}\end{array}$ & $\begin{array}{c}\text { Total } \\
\text { wildfire }\end{array}$ & $\begin{array}{c}\text { Wildfire } \\
\text { incidence } / \mathrm{km}^{2} \\
\end{array}$ & $\begin{array}{l}\text { Total Burnt } \\
\text { area ha }\end{array}$ & $\begin{array}{c}\text { Burnt } \\
\text { area } / \mathrm{km}^{2}\end{array}$ & $\begin{array}{c}\text { Total } \\
\text { wildfire }\end{array}$ & $\begin{array}{c}\text { Wildfire } \\
\text { incidence } / \mathrm{km}^{2}\end{array}$ & $\begin{array}{l}\text { Total burn } \\
\text { area (ha) }\end{array}$ & $\begin{array}{c}\text { Burnt } \\
\text { area/ } \mathrm{km}^{2}\end{array}$ \\
\hline $\begin{array}{l}\text { High Mountain/ } \\
\text { high Himalaya }\end{array}$ & 24763 & 221 & \multicolumn{6}{|c|}{ High Mountain/ } & 1.0 \\
\hline Middle hill & 23161 & 678 & 0.03 & 7630 & 0.3 & 2057 & 0.09 & 81128 & 3.5 \\
\hline Siwalik & 13964 & 748 & 0.05 & 30985 & 2.2 & 2236 & 0.16 & 88187 & 6.3 \\
\hline Tarai & 4211 & 218 & 0.05 & 9778 & 2.3 & 681 & 0.16 & 26858 & 6.4 \\
\hline Total & 66099 & 1865 & 0.14 & 93867 & 6.7 & 5630 & 0.43 & 222046 & 17.2 \\
\hline Average & - & - & 0.03 & - & 1.4 & - & 0.09 & - & 3.4 \\
\hline
\end{tabular}

\section{Density of wildfire incidence and burnt area}

In Nepal, average density of wildfire incidence varied according to physiographical regions. It was higher (0.09) incidence with 3.4 ha forest burnt area per $\mathrm{km}^{2}$ in 2016 than the average annual wildfire incidence of 0.03 with 1.4 ha burnt area per $\mathrm{km}^{2}$ during 2000-2015 (Table 2). Specifically, wildfire density was found to be higher in Tarai region. The recorded wildfire incidence and burnt area in this region was respectively 0.16 and 6.4 ha per $\mathrm{km}^{2}$ in 2016. However, the annual average annual incidence was 0.05 with burnt area 2.3 ha per $\mathrm{km}^{2}$ during 2000-2015.

Similarly, second higher wildfire density was found in Siwalik with having recorded 0.16 wildfire incidence with 6.3 ha forest burnt area per $\mathrm{km}^{2}$ in 2016, whereas 0.05 wildfire incidence with 2.2 ha forest burnt area per $\mathrm{km}^{2}$ during 2000-2015. On the other hand, the lowest density of wildfire incidences and burnt area were found in the High-Mountain and Himalayan region, where 0.03 incidence with 1.0 ha forest burnt area was recorded from 2000 to 2015. In India, Banerjee (2016) showed higher wildfire densities in April. Moreover, California Department of Forestry and Fire
Protection (CAL FIRE, 2016) reported higher wildfire densities across the California in 2016. Both research results are in agreement with the present research findings.

\section{Conclusion}

The spatial and temporal wildfire incidence and burnt area varied and it was found to be in increasing trends over the 17 years (20002016) period. The wildfire incidences, burnt area, wildfire density and length of the burning days were found to be higher in 2016 in comparison to 2000-2015. Moreover, the April was found to be the most wildfire vulnerable month. However, January, February, September, October and November were found to be the months of very less wildfire incidences, and July and August were observed to be the months of negligible wildfire incidence. Seasonally, the pre-monsoon was found to be highly wildfire sensitive period. Overall, there was higher wildfire incidence and burnt area per $\mathrm{km}^{2}$ in 2016 than average annual wildfire incidence and burnt area per $\mathrm{km}^{2}$ during 2000-2015. These findings will be useful for wildfire ecology, wildfire manager and wildfire management policy makers. 


\section{Acknowledgements}

We are thankful to the Central Department of Environmental Science, Tribhuvan University for providing opportunity to carry out the present research. Please acknowledge institutions or individual who have helped in some way for this research and manuscript writing. Moreover, great thank to Nepal Academy of Science and Technology, Government of Nepal for partial financial support. The authors extend special thanks to Mr. Purna Thapa for his assistance in mapping the burnt areas and other data analysis process.

\section{References}

Banerjee, B. (2016). Wildfires sweep through forests in northern India. Press trust of India via associated press from https://www.thenational.ae/world/forest-fires-sweep-acrossnorth-india-1.172583

Bowman, D.M., Balch J.K., Artaxo, P., Bond, W.J., Carlson J.M., Cochrane, M.A., D'Antonio C.M., Defries, R.S., Doyle, J.C., Harrison, S.P., Johnston, F.H., Keeley, J.E., Krawchuk, M.A., Kull, C.A., Marston, J.B., Moritz, M.A., Prentice, I.C., Roos, C.I., Scott,A.C., Swetnam, T.W., van der Werf, G.R., \& Pyne, S.J., (2009). Fire in the Earth System. Science, 324 (5926), 481-484.

Bowman, D. M., J. S., Williamson, G. J., Abatzoglou, J. T., Kolden, C. A., Cochrane, M. A., \& Smith, A. M. S. (2017). "Human exposure and sensitivity to globally extreme wildfire events." Nature Ecology \& Evolution, 1, 0058, 1-6.

CAL FIRE (2016). National Report of Wildland Fires and Acres Burned by State 2016". National Interagency Fire Center. Retrieved 1 February 2018. California Department of Forestry and Fire Protection (CAL FIRE).

Chettri, N., Shakya, B., Thapa, R., \& Sharma, E. (2008). Status of a protected area system in the Hindu Kush-Himalayas: An analysis of PA coverage. International Journal of Biodiversity Science E Management, 4(3), 164-178.

DFRS Nepal (2015). State of Nepal's Forests. Forest Resource Assessment (FRA) Nepal, Department of Forest Research and Survey (DFRS). Kathmandu.

FAO (2000). FRA 2000-Forest resources of Nepal, country report, Forest Resources Assessment (FRA) Programme, Food and agriculture Organization of the United Nations.

Flannigan, M.D., Krawchuk, M.A., de Groot, W.J., Wotton, B.M., \& Gowman, L.M. (2009) Implications of changing climate for global wildland fire. International Journal of Wild-land Fire, 18, 483-507.

Giglio, L., Randerson, J.T., \& van der Werf, G.R. (2013). Analysis of daily, monthly, and annual burned area using the fourthgeneration global fire emissions database (GFED4). Journal of Geophysical Research: Biogeosciences, 118(1), 317-328.

Giriraj, A., Babar, S., Jentsch, A., Sudhakar, S., \& Murthy, M. S. R. (2010). Tracking Fires in India Using Advanced Along Track Scanning Radiometer (A) ATSR Data. Remote Sensing, 2(2), 591-610.
Girardin, M.P., \& Mudelsee M. (2008). "Past and Future Changes in Canadian Boreal Wildfire Activity." Ecological Applications, 18(2), 391-406.

Hansen, J., Ruedy, R., Sato, M., \& Lo, K. (2010). "Global surface temperature change." Reviews of Geophysics, 48(4), 1-29.

Hartmann, D. L., Klein Tank, A. M. G., Rusticucci, M., Alexander, L. V., Bröannimann, S., Charabi, Y. A. R., \& Zhai, P. (2013). Observations: Atmosphere and surface. In Climate Change. 2013 the Physical Science Basis. Contribution of working Grpoup I to the Fifth Assessment Report of the Intergovernmental Panel on Climate Chan ge [Stocker, T.F., D. Qin, G.K. Plattner, M. Tignor, S.K. Allen, J. Boschung, A. Nauels, Y. Xia, V. Bex, and P.M. Midgley (eds)] Cambridge Unversity Press, Cambridge, United Kingdom and New York, NY, USA.

Huang, Y., Wu, S., \& Kaplan J.O. (2015). Sensitivity of global wildfire occurrences to various factors in the context of global change. Atmospheric Environment, 121, 86-92.

Jenner, L. (2017). "Report of Eastern Asian Fires Spotted by NOAA/NASA's Suomi NPP Satellite" National Aeronautics and Space Administration Retrieved 11November 2017 from https://www.nasa.gov/feature/goddard/2017/noaanasassuomi-npp-satellite-provides-copious-information.

Kothawale, D.R., Revadekar, J.V., \& Rupa Kumar, K. (2010). Recent trends in pre-monsoon daily temperature extremes over India. Journal of Earth System Science, 119(1), 51-65.

Kansakar, S.R., Hannah, D.M., Gerrard, J., \& Rees, G. (2004). Spatial pattern in the precipitation regime of Nepal. International Journal of Climatology, 24, 1645-1659.

Mallapur, C. (2016). Forest Fires Surge 30\% in 2016 reported in India Spend Journalism, Retrieved 11November 2017 from http://indiaspend.com.

Matin, M. A., Chitale, V. S., Murthy, M. S. R., Uddin, K., Bajracharya, B., \& Pradhan, S. (2017). Understanding forest fire patterns and risk in Nepal using remote sensing, geographic information system and historical fire data. International Journal of Wildland Fire, 26(4), 276-286.

Negi, G.C.S., Samal, P.K., Kuniyal, J. C., Kothyari, B.P., Sharma, R.K., \& Dhyani, P.P. (2012). Impact of climate change on the western Himalayan mountain ecosystems: an overview. Tropical Ecology, 53, 345-356.

Parajuli, A, Chand, D.B., Rayamajhi, B., Khanal, R., Baral, S., Malla, Y., \& Poudel, S. (2015) Spatial and temporal distribution of forest fires in Nepal. XIV World Forestry Congress, Durban, South Africa, 7-11.

Parisien, M.A., \& Moritz, M.A. (2009). Environmental controls on the distribution of wildfire at multiple spatial scales. Ecological Monographs, 79, 127-154.

Pechony, O., \& D. T. Shindell (2010). "Driving forces of global wildfires over the past millennium and the forthcoming century." Proceedings of the National Academy of Sciences of the United States of America, 107(45), 19167-19170. 
Pradhan, B., Shrestha, S., Shrestha, R., Pradhanang, S., Kayastha, B., \& Pradhan, P. (2013) Assessing climate change and heat stress responses in the Tarai Region of Nepal. Industrial Health, 51, 101-112. doi:10.2486/INDHEALTH.2012-0166

Randerson, J.T., Chen, Y, van Der Werf, G.R., Rogers, B.M., \& Morton, D.C. (2012) Global burned area and biomass burning emissions from small fires. Journal of Geophysical Research Biogeo-science, 117, 1-23

Richtel M., \& Fernanada S. (2016). Wildfires, Once Confined to a Season, Burn Earlier and Longer published in Science Times Newsletter Retrieved 11November 2017 from https://www.nytimes.com.

Rohini, P., Rajeevan, M., \& Srivastava, A. K. (2016). "On the Variability and Increasing Trends of Heat Waves over India." Scientific Reports 6: (26153)1-9

Shu, L., \& Xiaojun, K. (2001). Study of the Pattern of special Forest Fire Behavior by Using Satellite Remote Sensing. Fire Safety Science, 10 (3), 140-144

Singh, H., Arora, K., Ashrit, R., \& Rajagopal, E. N. (2017). "Verification of pre-monsoon temperature forecasts over India during 2016 with a focus on heat wave prediction". Natural Hazards and Earth System Sciences. 17(9), 1469-1485 Retrieved 11 November 2017.
Streets, D.G., Yarber, K.F., Woo, J.H., \& Carmichael, G.R. (2003): Biomass burning in Asia: Annual and seasonal estimates and atmospheric emissions. Global Biogeochemical Cycles, 17(4), $1-60$

Wang, S.Y., Yoon, J.H., Gillies, R.R., \& Cho, C. (2013). "What Caused the Winter Drought in Western Nepal during Recent Years?" Journal of Climate, 26(21), 8241-8256.

Westerling, A. L., Hidalgo, H. G., Cayan, D. R., \& Swetnam, T. W. (2006). "Warming and Earlier Spring Increase Western U.S. Forest Wildfire Activity". Science,313 (issue-5789), 940-943.

Yue, X., Mickley, L. J., Logan, J. A., \& Kaplan, J. O. (2013). "Ensemble projections of wildfire activity and carbonaceous aerosol concentrations over the western United States in the mid21st century". Atmospheric environment, 77, 767-780.

Zhao, M., \& Running, S.W. (2010). Drought-induced reduction in global terrestrial net primary production from 2000 through 2009. Science, 329, 940-943. 